\title{
Induction of granulomas in interferon- $\gamma$ gene- disrupted mice by avirulent but not by virulent strains of Mycobacterium tuberculosis
}

\author{
I. SUGAWARA, H. YAMADA, Y. KAZUMI*, N. DOI†, K. OTOMO, T. AOKI, S. MIZUNO, \\ T. UDAGAWA, Y. TAGAWA $\ddagger$ and Y. IWAKURA $\ddagger$
}

Molecular Pathology, *Bacteriology and $\uparrow$ Immunology Divisions, Research Institute of Tuberculosis, Japan Anti-tuberculosis Association, 3-1-24 Matsuyama, Kiyose, Tokyo 204 and $\ddagger$ Laboratory Animal Research Center, Institute of Medical Sciences, University of Tokyo, 4-6-1 Shiroganedai, Minato-ku, Tokyo 108, Japan

\begin{abstract}
To gain a better understanding of the pathological role of interferon- $\gamma$ (IFN- $\gamma$ ) in specific granuloma formation, IFN- $\gamma$ gene-deficient mice (BALB/c and C57BL/6) were produced. The IFN- $\gamma$ gene in embryonic stem (ES) cells was disrupted by inserting the $\beta$-galactosidase gene (lacZ) and the neomycin resistance gene (neo) at the translation initiation site in exon 1 by homologous recombination. Six-week-old IFN- $\gamma$-deficient and wild-type mice were inoculated with $1^{3}-10^{7}$ bacilli of various strains of Mycobacterium tuberculosis (Kurono, H37Rv, H37Ra and BCG Pasteur) through their tail veins. The mice were examined 7 weeks later for granuloma formation. The avirulent BCG Pasteur and H37Ra strains $\left(10^{3}-10^{4} \mathrm{bacilli} / \mathrm{ml}\right)$ induced granulomas in the spleen, liver and lungs of IFN- $\gamma$-deficient mice. The granulomas consisted of epithelioid macrophages and Langhans multinucleate giant cells, but lacked caseous necrosis. The virulent Kurono and $\mathrm{H37Rv}$ strains induced disseminated abscesses but not granulomas in various organs of IFN- $\gamma$-deficient mice and Mac-3-positive macrophages were not detected in the abscess lesions. These results suggest that IFN- $\gamma$ may be primarily responsible for macrophage activation and that other factor(s) may be involved in the granuloma formation mechanism.
\end{abstract}

\section{Introduction}

Interferon- $\gamma$ (IFN- $\gamma$ ), a cytokine secreted by activated $\mathrm{T}$ cells and natural killer cells, has immunomodulatory effects on several cell types [1]. IFN- $\gamma$ is one of the major cytokines responsible for the activation of macrophages that mediate non-specific, cell-mediated host defence [2,3]. Experiments with neutralising antibodies to IFN- $\gamma$ have shown a requirement in vivo for IFN- $\gamma$ in the activation of murine macrophages for microbicidal activity and in the induction of major histocompatibility complex (MHC) class II antigen on the surface of murine macrophages [4]. IFN- $\gamma$ has been shown to be an important mediator of macrophage activation in controlling a number of intracellular pathogens, including Leishmania major, Leish. donovani and Listeria monocytogenes [5-7].

It is of interest to analyse the mechanism of specific

Received 1 Sept. 1997; revised version accepted 14 Jan. 1998.

Corresponding author: Dr I. Sugawara. granuloma formation induced by Mycobacterium tuberculosis, M. leprae and other mycobacteria from the pathological and therapeutic points of view. It is important to prevent progression to granuloma which results in organ deformity - to be able to treat inflammatory diseases without granuloma formation would be ideal. Abundant IFN- $\gamma$ mRNA has been found in pleural tissues from patients with tuberculous pleuritis and in the lesions of the self-healing form of leprosy $[8,9]$. Thus, it is reasonable to speculate that there is a close association between IFN- $\gamma$ and granuloma formation.

To gain a better understanding of the pathological role of IFN- $\gamma$ in mycobacterial granulomas, mice that fail to produce IFN $-\gamma$ because of a targeted disruption of the gene encoding IFN- $\gamma$ were developed $[10,11]$. Although the critical role of endogenous IFN- $\gamma$ in macrophage fusion, cell recruitment and granuloma assembly was identified, other factor(s) may be involved in granuloma formation, because avirulent $M$. tuberculosis strains still induced typical granulomas in IFN- $\gamma$ gene-deficient mice. 


\section{Materials and methods}

Mice

Interferon- $\gamma$ gene-disrupted mice were generated as described previously [10]. The Bam HI fragment $(10.5 \mathrm{~kb})$ of the murine IFN $-\gamma$ genomic DNA clone was kindly provided by Dr. H. A. Young (NIH, Washington). A Kpn I fragment was subcloned from the Bam HI fragment and placed into Bluescript II. Then Lac Z gene and the neomycin-resistant gene (neo) were inserted into the newly created Hind III and the Cla I site of the IFN- $\gamma$ gene in which exon 1 was disrupted. The targeting vector was linearised with Not I. After electroporation and selection of A3-1 embryonic stem (ES) cells from a 129/SvJ mouse with the targeting vector, 10 ES cells were injected into the blastocoelic cavity and the blastocysts were cultured for $1-2 \mathrm{~h}$ in modified BWW medium. Embryos with visible blastocoele cavities were transferred to the uterus of pseudopregnant random-bred ICR recipients 2.5 days after coitus. The chimeric mice were crossed with wild-type mice, and the $F_{2}$ generations were used to breed the homozygous IFN$\gamma$-deficient mice that were used in the present experiments.

\section{Bacterial strains and mouse infections}

The experimental procedures were in accordance with the ARVO resolution on the use of animals in research. Permission (no. 972) to experiment on animals was given by the Animal Experiment Committee in the Research Institute of Tuberculosis. Four strains of $M$. tuberculosis (Kurono, H37Rv, H37Ra and BCG Pasteur) were grown in $7 \mathrm{H} 9$ medium (Difco) to mid-log phase. Wild-type BALB/c and C57BL/6 mice were age-matched (6-weeks-old) and sex-matched to IFN- $\gamma$ gene-deficient $\mathrm{BALB} / \mathrm{c}$ and $\mathrm{C} 57 \mathrm{BL} / 6$ mice. Each mouse in the experimental groups (consisting of 20 mice) was infected intravenously through the lateral tail vein with an inoculum of $10^{3}-10^{7} M$. tuberculosis bacilli suspended in $0.1 \mathrm{ml}$ of PBS and was killed 7 weeks later for morphological and molecular biological analysis. Animals were observed for 7 weeks because preliminary experiments had shown that this period was sufficient to allow granulomas to develop.

\section{Histological analysis}

Sections $(4 \mu \mathrm{m})$ from paraffin blocks containing formalin $10 \%$-fixed lung, liver, kidney and spleen were stained with haematoxylin and eosin and by the ZiehlNeelsen method for acid-fast bacilli (AFB). For polymerase chain reaction (PCR) analysis, the spleen and lung were sliced and fixed with periodate-poly-Llysine-paraformaldehyde (PLP) 1\% solution for $3 \mathrm{~h}$. For transmission electron microscopy, spleen, lung and liver were fixed with glutaraldehyde for $6 \mathrm{~h}$ and were post-fixed with osmium tetroxide $1 \%$ for $15 \mathrm{~min}$.

\section{Immunohistochemistry}

Immunohistochemistry was performed with the avidinbiotin complex (ABC) peroxidase (PO) as described in detail previously $[12,13]$. Anti-Mac-3 antibody (Pharmingen, San Diego, CA, USA) and anti-BCG antibody (Dakopatts, Copenhagen, Denmark) were each used at a final concentration of $10 \mu \mathrm{g} / \mathrm{ml}$ [14]. For negative control slides, all these steps were repeated, but with an irrelevant, isotype-matched, monoclonal antibody (MAb; anti-cytokeratin) or non-immune serum substituted for the primary antibody. Staining results were judged and scored independently by two workers (I.S and H.Y.).

\section{DNA preparation and PCR}

DNA from the spleen, liver and lungs was purified as described previously [15].

Primers corresponding to portions of the $M$. tuberculosis IS6110 and 19-kDa antigen DNA sequences were synthesised on a 381A DNA synthesiser (Applied Biosystems, Foster City, CA, USA). The amplification reaction mixture $(50 \mu \mathrm{l}$ total volume) contained $5 \mu \mathrm{l}$ of template DNA, as recommended by the Taq polymerase supplier (Perkin-Elmer Cetus, Norwalk, CT, USA). The samples were amplified through 30 cycles in a programmable thermal cycler (PerkinElmer Cetus) with a three-step cycle of denaturation for $1.5 \mathrm{~min}$ at $94^{\circ} \mathrm{C}$, annealing for $1.75 \mathrm{~min}$ at $60^{\circ} \mathrm{C}$ and extension for $2.5 \mathrm{~min}$ at $72^{\circ} \mathrm{C}$. The amplification products ( 314 and $245 \mathrm{bp}$ ) were analysed by electrophoresis through an agarose $2.0 \%$ gel with a Trisborate-EDTA buffer system and were visualised by ethidium bromide fluorescence [16,17].

\section{Cytokine assay}

The InterTest- $\gamma$ Mouse IFN- $\gamma$ ELISA kit (Genzyme Corporation, Cambridge, MA, USA) was used to quantify IFN- $\gamma$ levels in mouse serum. It is a solidphase ELISA employing a 96-well microtitration plate pre-coated with anti-mouse IFN- $\gamma$ antibody to capture IFN- $\gamma$ present in test samples. A standard curve was obtained by plotting the concentrations of mouse IFN- $\gamma$ standards versus absorbance. The mouse IFN- $\gamma$ concentrations in the experimental samples were then determined from the standard curve. The detection limit of this assay was determined to be $5 \mathrm{pg} / \mathrm{ml}$ after statistical analysis of ELISA results.

\section{Results}

\section{Histology of infections}

Mice were killed 7 weeks after being infected and formalin-fixed sections were stained with haematoxylin and eosin and by the Ziehl-Neelsen method. Previous studies had demonstrated that 7 weeks was sufficient time for granulomatous lesions to develop in wild-type $\mathrm{BALB} / \mathrm{c}$ and $\mathrm{C} 57 \mathrm{BL} / 6$ mice after injection of $10^{5}$ 


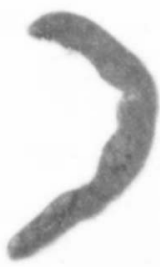

A
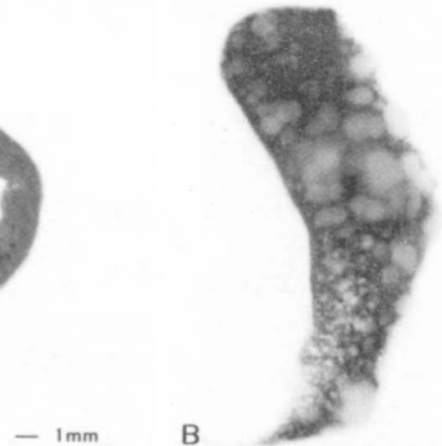

Fig. 1. Macroscopic views of the spleens from: A, a wildtype $\mathrm{BALB} / \mathrm{c}$ mouse infected with $\mathrm{BCG}$ Pasteur bacilli; $\mathbf{B}$, an IFN- $\gamma$ gene-disrupted BALB/c mouse infected with the same strain. Note the prominent splenomegaly and granulomatous lesions of various sizes (B). No granulomatous lesions are seen in $\mathbf{A}$. bacilli of strains Kurono or H37Rv into a lateral tail vein. Fig. 1B shows representative granulomas in the spleen with splenomegaly from IFN- $\gamma$ knockout mice. Various granulomas were induced in the spleen, liver and lungs of wild-type mice when $>10^{5}$ bacilli of virulent strains Kurono or H37Rv were injected intravenously. Granulomas were seen in the lymph follicles of the spleen, in the Glisson sheaths of the liver and near the pulmonary vessels of the lungs. Ziehl-Neelsen staining showed that $M$. tuberculosis bacilli were scattered throughout the granulomas. Tubercle bacilli were found in the epithelioid cells. When $10^{3}-10^{7}$ bacilli of avirulent strains H37Ra or BCG Pasteur were injected into the wild-type mice, granulomas were rarely formed. On the other hand, when $10^{4}$ bacilli of strains H37Ra or BCG Pasteur were injected intravenously into the IFN- $\gamma$ gene-

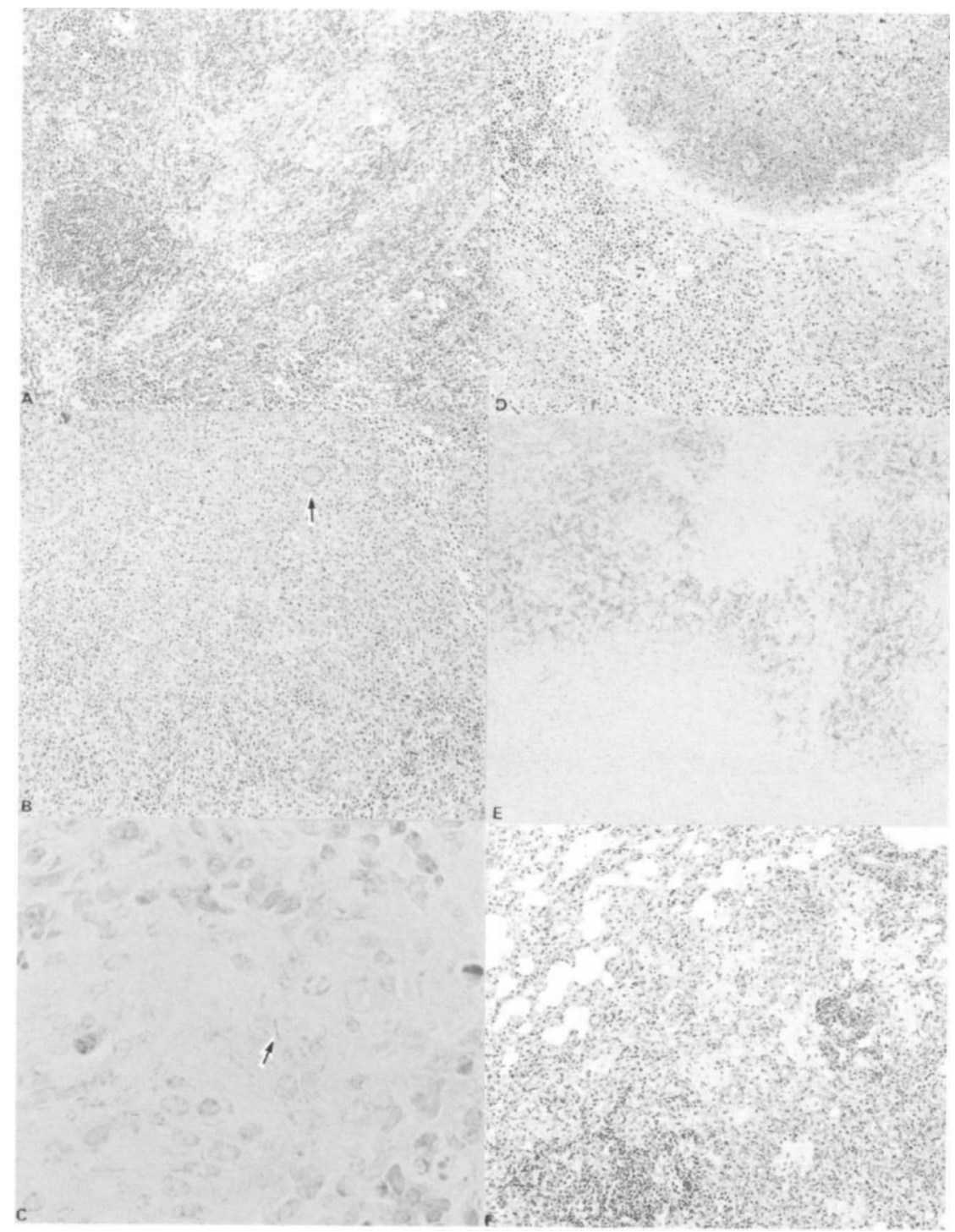

Fig. 2. Representative histology of infected organs from wild-type BALB/c (A) and IFN- $\gamma$ gene-deficient (knockout) BALB/c mice (B, D, F). H\&E staining except $\mathbf{C}$ and $\mathbf{E}$ (Ziehl-Neelsen stain). A, The spleen of a wild-type mouse infected with the virulent Kurono strain; a granulomatous lesion is seen in the lymph follicle $(\times 100)$. B, Splenic granuloma with Langhans multinucleate giant cells $(\rightarrow$ ) lacking central necrosis in a knockout mouse infected with BCG Pasteur bacilli. $(\times 80)$. C, Splenic granuloma with tubercle bacilli $(\rightarrow)$ in $\mathbf{B}(\times 8000$, immersed in oil $)$. D, Abscess lesion in spleen from a knockout mouse infected with Kurono strain $(\times 80)$; abscess formation, but not granuloma is seen. E, Abscess lesion with many tubercle bacilli; the central abscess lacks bacilli. F, Pulmonary granuloma with foamy cells in knockout mouse infected with BCG Pasteur $(\times 80)$. 

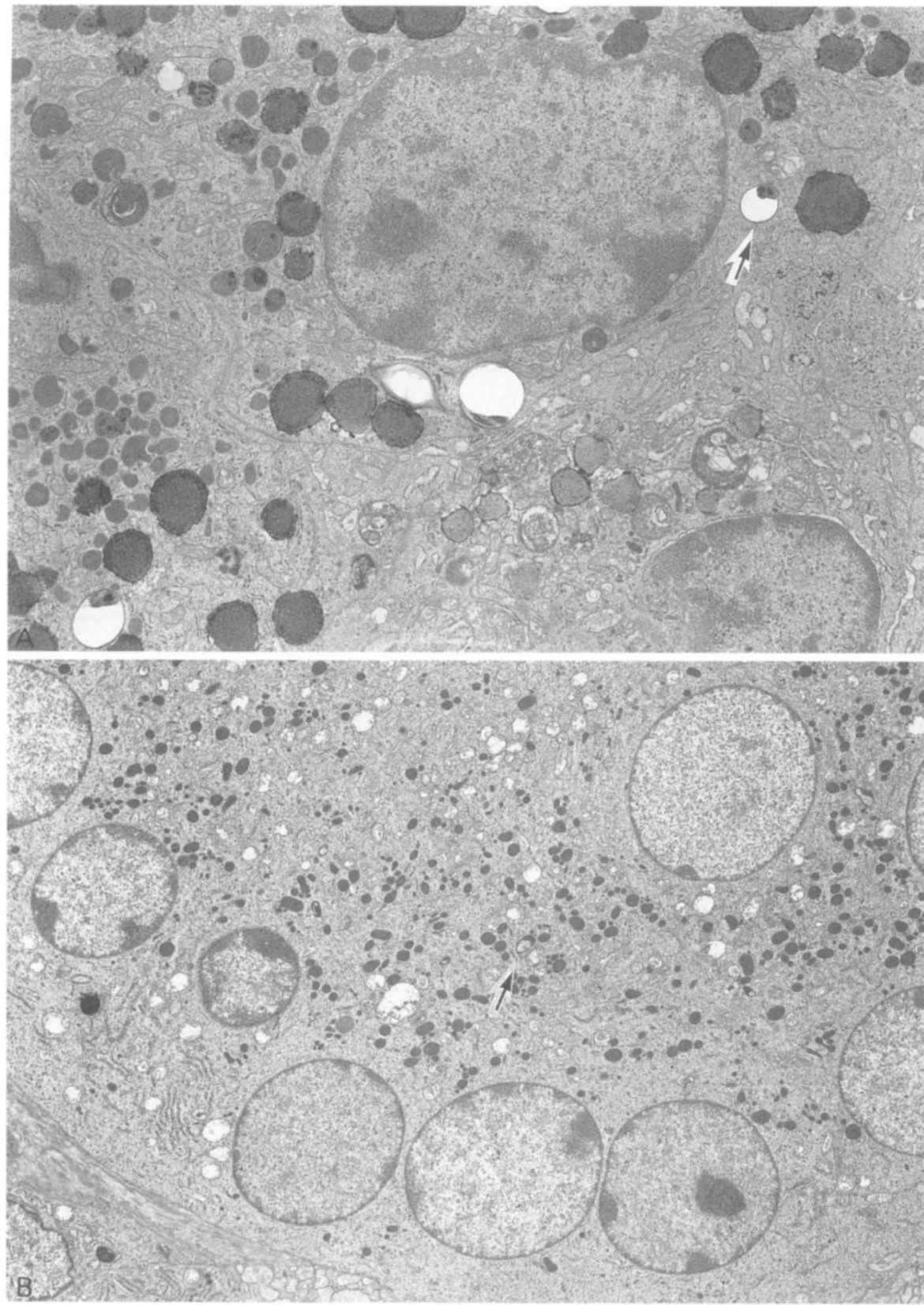

Fig. 3. Electron micrographs of splenic granulomas from: A, a wild-type C57BL/6 mouse infected with Kurono strain the epithelioid cell can be seen to phagocytose the bacillus $(\rightarrow) .(\times 7500) ; \mathbf{B}$, an IFN- $\gamma$ knockout C47BL/6 mouse infected with BCG Pasteur $(\times 4000)$; the multinucleate giant cell contains lysosomes with bacillus fragments $(\rightarrow)$.

deficient $\mathrm{BALB} / \mathrm{c}$ and $\mathrm{C} 57 \mathrm{BL} / 6$ mice, conspicuous granulomas were induced in the spleen, liver and lungs (Fig. 2). The granulomas consisted of epithelioid cells, Langhans-type multinucleate giant cells and lymphocytes. Central necrosis was not found. Caseous necrosis was not found even 6 months after the mice were infected. Central necrosis was surrounded by epithelioid macrophages and connective tissues (data not shown).

Epithelioid cells and Langhans multinucleate giant cells contained tubercle bacilli. Microscopic granulomas were recognised in the liver and lungs. The pulmonary granulomas consisted of foamy cells and epithelioid cells, but not Langhans multinucleate giant cells.

When the virulent $\mathrm{H} 37 \mathrm{Rv}$ and Kurono strains $\left(10^{6}\right.$ bacilli) were injected into the IFN- $\gamma$ gene-disrupted mice, they induced only disseminated inflammation, mainly abscesses, in major organs including lung, liver, spleen, kidney and heart without forming granulomas (Fig. 2).

Macrophages and epithelioid cells were not recognised near the abscess lesions. The abscess lesions displayed 


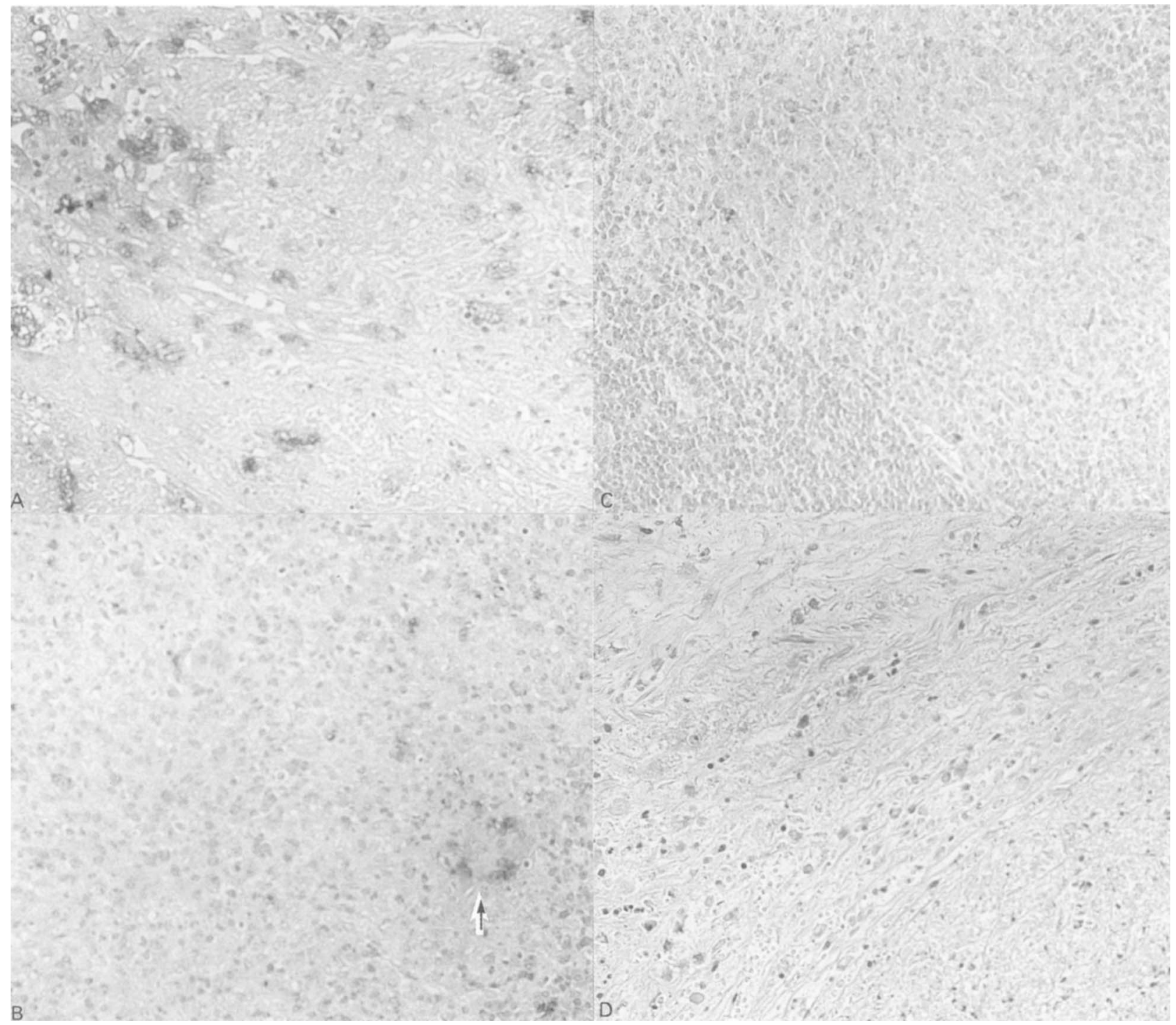

Fig. 4. Immunohistochemistry of granulomatous lesions immunostained with anti-BCG antibody (A and B) and antiMac-3 MAb (C and D) ( $\times 80)$; ABC-PO method, counterstained with haematoxylin. (A) Splenic granuloma from an IFN- $\gamma$ knockout mouse infected with BCG Pasteur; the multinucleate giant cell contains immunoreactive BCG. (B) The epithelioid cells of human pulmonary tuberculosis as a positive control are intensely immunostained with anti-BCG. (C) Granulomatous lesion in the spleen from IFN- $\gamma$ knockout BALB/c mouse positively immunostained with anti-Mac$3 \mathrm{MAb}$. (D) The abscess lesion of the spleen infected with the virulent Kurono strain is not immunostained, indicating the absence of epithelioid macrophages.

central necrosis, neutrophils and cell debris. ZiehlNeelsen staining revealed a massive halo of tubercle bacilli surrounding the abscess lesions (Fig. 2E). There was no difference in resistance to mycobacterial strains between the $\mathrm{BALB} / \mathrm{c}$ and $\mathrm{C} 57 \mathrm{BL} / 6$ mice strains; they were both susceptible to $M$. tuberculosis infection.

Similar pathology was observed by electron microscopy. Discrete granuloma formation was noted in wild-type mice infected with virulent $M$. tuberculosis. Granulomas mainly consisting of epithelioid cells were not conspicuous in IFN- $\gamma$ gene-deficient mice infected with virulent $M$. tuberculosis strains (Fig. 3). The granulomas induced by avirulent $M$. tuberculosis strains consisted of epithelioid cells and Langhans multinucleate giant cells (Fig. 3). Both possessed obvious vacuoles, a few of which contained bacterial remnants.

Immunohistochemically, BCG antigens were present in epithelioid cells and Langhans multinucleate giant cells. The granulomatous lesions were immunostained by the anti-Mac-3 murine MAb; in fact, the epithelioid and Langhans multinucleate giant cells were intensely immunostained. There were no Mac-3positive macrophages around the abscess lesions (Fig. 4). 


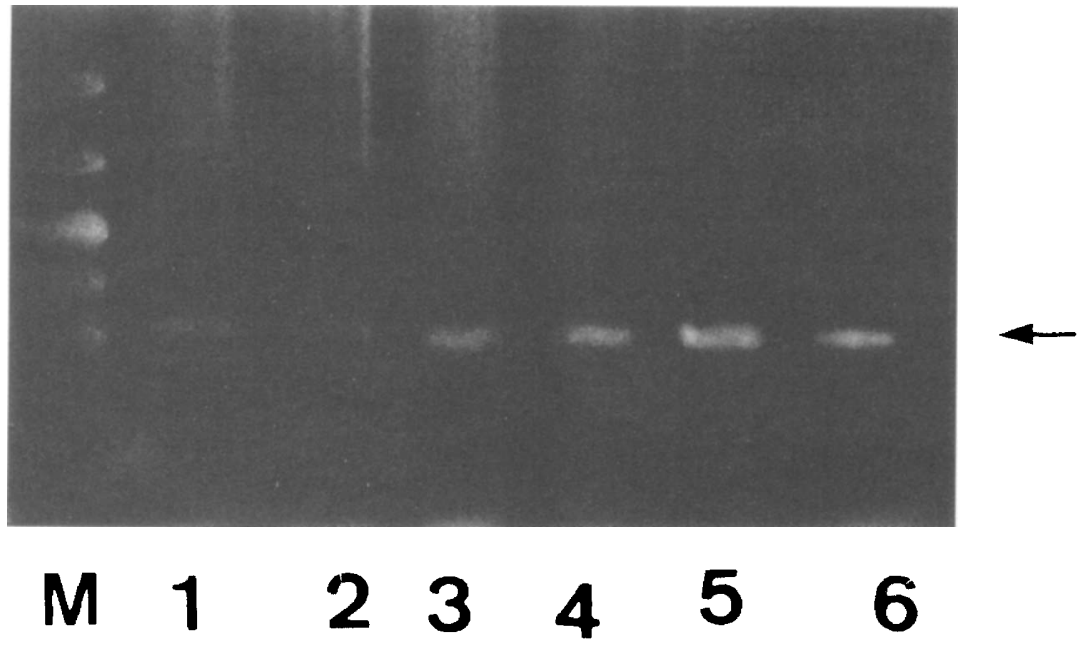

Fig. 5. PCR products of $M$. tuberculosis $19-\mathrm{kDa}$ antigen separated in agarose $2 \%$ gel. M, size marker; lane 1, DNA from Kurono strain; 2, DNA from strain H37Rv; 3, DNA from BCG Tokyo; 4, DNA from BCG Pasteur; 5, DNA from the spleen of an IFN- $\gamma$ knockout mouse infected with BCG Pasteur; 6, DNA from the spleen of an IFN- $\gamma$ knockout mouse infected with Kurono strain. The 19-kDa antigen gene-specific amplified band (314 bp) $(\leftarrow)$ was recognised in lanes $1-6$.

\section{PCR analysis}

M. tuberculosis-specific 19-kDa antigen gene fragments and IS6110-related DNA fragments were detected by PCR analysis in spleen, liver and lungs of the wild-type and IFN- $\gamma$ gene-deficient mice infected with virulent and avirulent mycobacterial strains. Fig. 5 shows that the $19-\mathrm{kDa}$ antigen gene-specific PCR products $(314 \mathrm{bp})$ were recognised in the infected spleen tissues.

\section{Cytokine assay}

IFN- $\gamma$ was measured in serum samples from wild-type and IFN- $\gamma$ gene-disrupted mice infected with BCG Pasteur by a solid-phase ELISA. IFN- $\gamma$ was not detected in sera from BALB/c and C57BL/6 IFN- $\gamma$ gene-deficient mice infected with BCG Pasteur, whereas the IFN- $\gamma$ concentrations of sera from wildtype BALB/c and C57BL/6 mice infected with BCG Pasteur were $6000 \mathrm{SD} 150$ and $7000 \mathrm{SD} 230 \mathrm{pg} / \mathrm{ml}$, respectively.

\section{Discussion}

In this study virulent $M$. tuberculosis strains induced disseminated inflammation in various organs of IFN- $\gamma$ gene-disrupted mice, but avirulent $M$. tuberculosis strains induced typical granulomas in the major organs of these mice. Multinucleate giant cells simulating Langhans type giant cells were frequently observed. The appearance of these giant cells may be characteristic of granulomas induced in IFN- $\gamma$ knockout mice, because no multinucleate giant cells were seen in other murine granulomas. Although BCG Pasteur-infected IFN- $\gamma$ knockout mice were observed for 6 months, caseous necrosis was not observed although mild central necrosis was sometimes recognised. There was no evidence of macrophages surviving in the abscess lesions at a time when bacterial loads reached very high levels [18]. This finding was confirmed by the absence of Mac-3-positive macrophages in or near the abscess lesions. These data demonstrate that mice lacking a functional gene for IFN- $\gamma$ are unable to contain and control a virulent $M$. tuberculosis infection. No IFN- $\gamma$ was detected in sera of IFN- $\gamma$ gene-deficient mice infected with $M$. tuberculosis strains as evaluated by ELISA.

Studies of this mouse model may have relevance to tuberculosis in AIDS patients and elderly people [19]. As CD4 function declines in HIV infection, IFN- $\gamma$ production by helper $\mathrm{T}$ cells is reduced [20]. The pattern of $M$. tuberculosis infection in AIDS patients is frequently more diffuse than that seen in classical tuberculosis, but is characterised by extensive tissue necrosis. A similar pattern was induced in CD4 genedisrupted mice (data not shown). A similar pattern of infection is also recognised in elderly patients with tuberculosis who are immunocompromised. There are some striking similarities in the pattern of infection in these IFN- $\gamma$ gene knockout mice; greater bacterial growth and dissemination and greater necrosis, particularly of liver and spleen, are observed, which is relative to the infection in wild-type mice. The present data also imply that IFN- $\gamma$ serum concentrations would be reduced in patients with advanced tuberculosis. An earlier study measured reduced IFN- $\gamma$ concentrations in the sera of such patients [21]. This mouse model may provide a useful model for studying tuberculosis in immunocompromised patients.

Evidence for a low state of activation of macrophages harvested from IFN- $\gamma$ gene-disrupted mice infected with $M$. bovis BCG has been reported previously [22]. 
In the present study $10^{7} \mathrm{BCG}$ Pasteur were injected into the IFN- $\gamma$ knockout mice via a tail vein and these mice did not die. The major difference between these studies is that in the knockout mice in the present study, exon 1 was disrupted, whereas exon 2 was disrupted in the earlier study of IFN- $\gamma$ knockout mice. The BCG Pasteur strain used by Dalton et al. may differ in virulence from the BCG Pasteur in the present study. It is necessary to compare the BCG strains with each other to elucidate this factor. It is known that macrophages in a low state of activation have low levels of class II MHC molecules. Therefore, they are incapable of controlling the proliferation of virulent $M$. tuberculosis, but they can partially control avirulent $M$. tuberculosis.

Data from the present study also suggest that cytokines other than IFN- $\gamma$ can mediate the initiation of granuloma formation; however, as avirulent $M$. tuberculosis is able to induce typical granulomas in the absence of IFN- $\gamma$, it is safe to say that IFN- $\gamma$ may be primarily involved in macrophage activation. Kindler et al. found that a neutralising antibody to TNF disrupted the architecture of granulomas and increased bacterial numbers in mice infected with an avirulent BCG strain of $M$. bovis [23]. Amiri et al. observed that administration of TNF restored the granulomatous response to Schistosoma eggs in SCID mice [24]. Thus, it is reasonable to say that TNF contributes to the formation of granulomas, and that IFN- $\gamma$ appears to be essential for successful macrophage fusion, cell recruitment and granuloma formation. Macrophages secrete IL- $1 \alpha$ and $\beta$. 'IL-1 may be essential for granuloma formation, because in a preliminary experiment granulomas were not seen in IL-1 gene-deficient mice infected with BCG Pasteur.

It will be possible to clarify the roles of TNF and IL-1 in granuloma formation in further studies with TNF and IL-1 gene-disrupted mice strains that were established recently. The IFN- $\gamma$ knockout mouse may prove useful for evaluating and testing new strategies of immunotherapy and chemotherapy for tuberculosis and other intracellular infections.

\section{References}

1. Vilcek J, Gray PW, Rinderknecht E, Sevastopoulos CG. Interferon $\gamma$ : a lymphokine for all seasons. Lymphokines 1985; 11: 1-32.

2. Schreiber RD, Celada A. Molecular characterization of interferon $\gamma$ as a macrophage activating factor. Lymphokines 1985; 11: $87-118$.

3. Mackaness GB. Cellular resistance to infection. $J$ Exp Med 1962; 116: 381-406.

4. Buchmeier NA, Schreiber RD. Requirement of endogenous interferon- $\gamma$ production for resolution of Listeria monocytogenes infection. Proc Natl Acad Sci USA 1985; 82: 7404-7408.
5. Belosevic M, Davis CE, Meltzer MS, Nacy CA. Regulation of activated macrophage antimicrobial activities. Identification of lymphokines that cooperate with IFN- $\gamma$ for induction of resistance to infection. J Immunol 1988; 141: 890-896.

6. Murray HW, Rubin BY, Rothermel CD. Killing of intracellular Leishmania donovani by lymphokine-stimulated human mononuclear phagocytes: evidence that interferon-gamma is the activating lymphokine. $J$ Clin Invest 1983; 72: 1506-1510.

7. Kinderlen AF, Kaufmann SHE, Lohmann-Matthes M-L. Protection of mice against the intracellular bacterium Listeria monocytogenes by recombinant interferon. Eur $J$ Immunol 1984; 14: $964-967$.

8. Barnes PF, Fong S-J, Brennan PJ, Twomey PE, Mazumder A, Modlin RL. Local production of tumor necrosis factor and IFN-gamma in tuberculous pleuritis. J Immunol 1990; 145: $149-154$.

9. Yamamura M, Uyemura K, Deans RJ et al. Defining protective responses to pathogens: cytokine profiles in leprosy lesions. Science 1991; 254: 277-279.

10. Tagawa Y, Sekikawa K, Iwakura Y. Suppression of concanavalin $\mathrm{A}$-induced hepatitis in $\mathrm{IFN}-\gamma^{-/-}$, but not in TNF- $\alpha^{-1-}$, mice: role for IFN- $\gamma$ in activating apoptosis in hepatocytes. J Immunol 1997; 159: 1418-1428.

11. Taylor AP, Murray HW. Intracellular antimicrobial activity in the absence of interferon- $\gamma$ : effect of interleukin-12 in experimental visceral leishmaniasis in interferon- $\gamma$ genedisrupted mice. J Exp Med 1997; 185: 1231-1239.

12. Hsu SM, Raine L, Fanger $H$. Use of avidin-biotin-peroxidase complex $(\mathrm{ABC})$ in immunoperoxidase techniques: a comparison between $\mathrm{ABC}$ and unlabeled antibody (PAP) procedures. $J$ Histochem Cytochem 1981; 29: 577-580.

13. Sugawara I, Yamada H, Nakamura $\mathrm{H}$ et al. Preferential expression of the multidrug-resistance-associated protein (MRP) in adenocarcinoma of the lung. Int $J$ Cancer 1995; 64: $322-325$.

14. Ralph P, Ho M-K, Litcofsky PB, Springer TA. Expression and induction in vitro of macrophage differentiation antigens on murine cell lines. J Immunol 1983; 130: 108-114.

15. Wilson K. Preparation of genomic DNA from bacteria. In: Ausubel FM, Brent R, Kinston RE et al. Current protocols in molecular biology, vol 1. New York, Wiley Interscience. 1990: 2.4.1-2.4.2.

16. Thierry D, Brisson-Noël A, Vincent-Lévy-Frébault V, Nguyen S, Guesdon J-L, Gicquel B. Characterization of a Mycobacterium tuberculosis insertion sequence, IS 6110, and its application in diagnosis. J Clin Microbiol 1990; 28: 2668-2673.

17. Young D, Lathigra R, Hendrix R, Sweetser D, Young RA. Stress proteins are immune targets in leprosy and tuberculosis. Proc Natl Acad Sci USA 1988; 85: 4267-4270.

18. Cooper AM, Dalton DK, Stewart TA, Griffin JP, Russell DG, Orme IM. Disseminated tuberculosis in interferon $\gamma$ genedisrupted mice. J Exp Med 1993; 178: 2243-2247.

19. Flynn JL, Chan J, Triebold KJ, Dalton DK, Stewart TA, Bloom BR. An essential role for interleukin $\gamma$ in the resistance to Mycobacterium tuberculosis infection. J Exp Med 1993; 178: 2249-2254

20. Murray HW, Rubin BY, Masur G, Roberts RB. Impaired production of lymphokines and immune (gamma) interferon in the acquired immunodeficiency syndrome. N Engl J Med 1984; 310: $883-889$.

21. Jitsukawa T, Nakajima S, Sugawara I, Mori S, de Ley $M$ Characterization of murine monoclonal antibodies to human interferon-gamma (IFN- $\gamma$ ) and their application for sandwich enzyme-linked immunosorbent assay (ELISA). Microbiol Immunol 1987; 31: 809-820.

22. Dalton DK, Pitts-Meek S, Keshav S, Figari IS, Bradley A Stewart TA. Multiple defects of immune cell function in mice with disrupted interferon- $\gamma$ genes. Science 1993; 259: $1739-1742$.

23. Kindler V, Sappino A-P, Grau GE, Piguet P-F, Vassali P. The inducing role of tumor necrosis factor in the development of bactericidal granulomas during BCG infection. Cell 1989; 56: 731-740.

24. Amiri P, Locksley RM, Parslow TG et al. Tumor necrosis factor $\alpha$ restores granulomas and induces parasite egg-laying in schistosome-infected SCID mice. Nature 1992; 356: 604-607. 